\title{
Culture and Igbo notions of masculinity in Nigerian children's literature
}

\section{Sunday Joseph Ayodabo}

\section{Culture and Igbo notions of masculinity in Nigerian children's literature}

Children's literature conveys the cultural and indigenous artistic experiences of the people to whom it is attributed. Earlier studies on modern Nigerian children's literature focus mainly on the representation of moral etiquette with little attention to gender. The twin theme of culture and masculinity has not been paid close attention by scholars of children's literature in Nigeria. In applying Igbo notions of masculinity, in this article I examine the role of oral tradition and culture in the construction of masculine identity in children's literature in Nigeria using Ifeanyi Ifoegbuna's Folake and Her Four Brothers, Anthonia Ekpa's Edidem Eyamba and the Edikang-lkong Soup, and Ikechukwu Ebonogwu's The Champion of Echidime. I show how the ideals of masculinity, as visible and permissible in the traditional Igbo society, are, in particular, constructed and communicated through various oral and cultural norms such as praise poetry, war songs and dance, wrestling, and drumming. I reveal that oral and cultural traditions in children's literature reflect attributes such as strength, toughness, honour, protection, respect, heterosexual desirability, and the projection of self-pride as acceptable and embraced masculine values among the Igbo in Nigeria. I also demonstrate how oral and cultural tradition is replete with masculine ideologies and messages that promote male dominance in the Igbo society. Keywords: oral traditions and culture, masculinity, Igbo masculinity, literature, gender, children's literature.

\section{Introduction}

Modern Nigerian children's literature reflects socio-cultural experiences and conduct that characterise children. This, no doubt, attests to the sociology of Nigerian literature. In other words, children's literature in Nigeria, and by extension Africa, conveys the cultural heritage and values of the people. Its nature is essentially cultural and didactic. Indeed, from folktales, to myths, proverbs, riddles, and even epic narrations, there is always a teaching to glean and a value to instil in the child. Modern Nigerian children's literature is, therefore, "the repository of the cultural life of the people and is a major source of education for the young everywhere" (Ojaide, "Modern African literature and cultural identity" 45). That is why most Nigerian children's literary texts are stories adapted from the gamut of Nigerian cultural life and customs.

It is, therefore, understandable that studies on children's literature in Nigeria have focused more on the didactic import and richness of oral and cultural traditions, a feature that is intrinsic to the cultural development of children in Nigeria (Emenyonu 584; Diala-Ogamba 54; Sackeyfio 6; Uko 17). In the scholarly works highlighted above, the primary concerns have not gone beyond the various forms of oral and cultural traditions and their values. However, the potential impact of children's literature on young readers is invaluable because children's literature may convey didactic elements, as well as ideals and behaviours that are considered acceptable in the society, including gender behavioural norms. Many children's stories have the potential to shape and affirm gender identities of readers and depict stereotypical images for their futures. A lot of research has provided insights into oral and cultural traditions and how they impact men's behaviours and attitudes in Africa (Oha 18; Turner 196; Ojaide, "Deploying Masculinity in African Oral Poetic Performance: The Man in Udje" 76; Kiyimba, "Men and Power: Masculinity in the Folktales and Proverbs of the Baganda" 35). For instance, in his semiotic study of Igbo proverbs, Oha argues that society tends to neglect the chauvinist tone of oral traditions due to its importance and value-carrying roles. Oha declares: "in the male-dominated Igbo culture particularly, and in some other

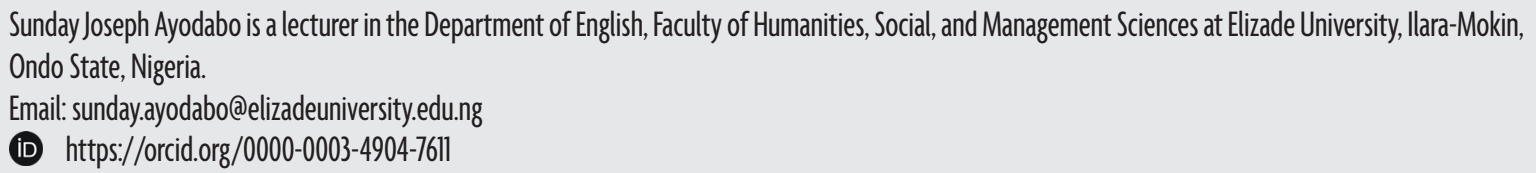

DOl: https://doi.org/10.17159/tl.v58i2.8804

DATES:

Submitted: 18 August 2020; Accepted: 22 June 2021; Published: 21 September 2021 
African cultures as well, proverbs are appropriated by men to uphold themselves as producers and custodians of knowledge which women are thought to be incapable of" (18). Furthermore, Turner explores the aspect of male sexuality and the hierarchy of gender in contemporary oral praise poetry of Zulu men. Turner identifies attributes such as virility, sexual prowess, physical attractiveness, strength, and the ability to fight as the predominant features in the praises of Zulu males. Turner further maintains that the predominant qualities are those which serve to reinforce the acceptable male stereotype in contemporary times (196). Kiyimba, in his investigation of the configuration of male power in the oral traditions of the Baganda in Uganda, argues that folktales and proverbs of the Baganda greatly contribute to a process that constructs men as dominant. He reveals that representations of males as boys, husbands, fathers, and political leaders in Baganda folktales and proverbs "are accumulative social constructs that have absorbed many factors and are part of the various mechanisms that the system uses to sustain notions of masculine superiority" ("Men and Power" 36). In another study, Kiyimba examines the portrayal of boys and girls in Baganda oral literature. He notes that gender stereotyping is evident in the oral literature of the Baganda, "as a complex socialisation process that begins in infancy" ("Gendering social destiny" 268). According to him, boys are well received and trained to inherit the political and social space while the girl, portrayed as the weaker sex, must strengthen her role by linking herself primarily to the male sex by using her physical beauty. Ojaide also discusses Urhobo notions of masculinity as expressed through oral poetic performance known as udje, a unique type of Urhobo poetry-song in Nigeria in which the male dancers are dressed in a war-like manner. Ojaide reveals that udje dramatises toughness, honour, propriety, the capacity for revenge or retaliation, and the projection of self-pride, all of which are the values of Urhobo's notions of masculinity ("Deploying masculinity" 76).

In addition, existing scholarship in children's literature provides valuable insights into representations of masculinity that might be useful. It has been found, for example, that children's literature is generally prone to imbalance in gender representations, with males being portrayed as brave, resilient, violent, and unemotional while females are represented in a one-dimensional and stereotypical way as helpless queens and princesses and weak, emotional, and passive characters (Nodelman 2). At the same time, intersections of masculinity with culture add interesting layers of representation that warrant specific examination. It is against this background that I investigate the intersection between culture and masculinity in Nigerian children's literature. Specifically, the discussion is projected through a textual analysis of some Igbo oral and cultural elements such as wrestling, war songs and dance, praise poetry, and drumming in some randomly selected Nigerian children's texts. Unlocking the means through which the selected texts construct masculinity provides possible insights into how masculinity is perceived, lived, and practised in traditional Igbo society, and how such cultural practices appear as part of a broader mechanism that perpetuates the legacy of male dominance.

\section{Masculinity in the African context}

Masculinity has been defined as a collective and unnatural feature of gender identity. It is fluid and socially constructed. According to Ayodabo and Amaefula, "there are hierarchies and rankings of power relations between different classes of men in each society" (2). Hence, there is no one overarching masculinity but variations of masculinities that exist in different societies, across different historical epochs, and are influenced by factors such as sex, race, class, and culture. In Africa, for instance, factors such as culture, colonialism, religion, economic freedom, class structure, and poverty are constitutive of the different forms that masculinity takes. In all the forms of masculinities, hegemonic masculinity - the form of masculinity which reinforces the dominance of men over women and other lesser men-is the most celebrated in most societies. However, hegemonic masculinity is claimed to be predominantly the masculinity of working-class white men, and as a result, has been scrutinised and found wanting (Ratale 117; Mfecane, "Ndiyindoda' [I am a man]: theorising Xhosa masculinity" 206).

In Africa, scholars have also steadily moved towards an inclusive understanding of masculinity. Important studies have contributed to the evolving field of masculinity, with attention to the understanding of what it means to be a man in various social, cultural, and historical African contexts (Ouzgane and Morrell 7; Mugambi and Allan 4). These studies draw on a variety of subject areas including history, film studies, popular culture, oral art, and cultural studies to illuminate the processes by which masculinity is produced, constructed, contested, and renegotiated in Africa. These works also analyse literary and cultural materials from the perspectives of men's struggle against economic and psychological vulnerabilities and their aggressive feelings towards menacing women as a response to their struggles. What is significant in all these essays is that they provide a space for reflection 
on the contemporary theory of gender and masculinity, including the question of how Western masculinities act in relation to indigenous masculinities. To answer these questions, African scholars have also identified alternative theories and ways to analyse men in Africa, including the articles "Analysing males in Africa: Certain useful elements in considering ruling masculinities" and "Hegemonic African masculinities and men's heterosexual lives: Some uses for homophobia" by Ratele, and "Ndiyindoda" [I am a man]: theorising Xhosa masculinity" and "Towards African-centred theories of masculinity" by Mfecane.

This study follows similar dimensions by analysing the texts through the understanding of masculinity from the perspective of traditional Igbo society, a group of people from the Eastern part of Nigeria. Gender roles and masculine ideology are well entrenched among the Igbo (Achebe; Odimegwu, Pallikadavath, and Adedini 221). In his famous novel, Things Fall Apart (1958), Achebe provides a glimpse of traditional Igbo masculine norms and values. He shows that men enact and achieve masculinity in traditional Igbo society through successful farming, wrestling victories, ownership of a large family system, earning titles, as well as the ability to effectively manage a household, among others. These masculine values are also sustained through gender socialisation processes of storytelling, communal activities, birth names, social institutions, and age-group and family systems. For instance, boys are told stories of war, etc. while girls are told 'softer' (folk)tales focused on animals, morality, etc. Within the community, women are more active in the domestic space (especially in cooking in preparation for a communal activity) and function as spectators in the public space (especially in wrestling and masquerade performances), while men play lead roles in both spaces: domestic and public. Men and boys are socialised through these systems of gender practices, seeing themselves as better, smarter, and more authoritative than females. This is why boys are favoured at birth, "groomed to be brave, confident, audacious, fearless and virile, whereas girls are raised to be soft, submissive, passive, and frail and gentle" (Odimegwu, Pallikadavath, and Adedini 221). This quiet, yet thorough, instruction on individual gender roles is rooted in the Igbo culture and entrenched in each gender as they grow up.

The scope of this study covers Nigerian children's short fiction only and stories on Igbo norms and culture. The selected texts are Ifeanyi Ifoegbuna's Folake and Her Four Brothers, Anthonia Ekpa's Edidem Eyamba and the Edikang-Ikong Soup, and Ikechukwu Ebonogwu's The Champion of Echidime. Since I examine notions of Igbo masculinity, all the texts considered are written by Igbo writers and contain dominant notions of Igbo masculinity. I recognise that there are other ethnic groups in Nigeria, however, I have limited this study to the narratives written by Igbo writers solely because they offer one of the most interesting and unique discourses on masculinity in children's literature in Nigeria. All the texts were read repeatedly for initial understanding of the data. Though the texts are all written in English, some texts infused with local Igbo dialect were translated and transcribed with the help of an Igbo translator. The narratives were then subjected to textual analysis.

\section{Analysis and discussion: Oral traditions, culture, and construction of masculinity}

All the texts studied in this article have different forms of oral and cultural traditions in which men have prominence.

\section{The Champion of Echidime}

Ikechukwu Ebonugwu's The Champion of Echidime tells the story of Dimgba, a wrestler whose victories in wrestling competitions have been a source of pride to his community, Echidime. Dimgba is well-built and is popular in the society because of his wrestling exploits. The story begins with the villagers anticipating the year's competition, while also revelling in the victories and strength of the Echidime's champion, Dimgba. In the competition, Dimgba goes on to beat every man, including Mbonu, his fiercest rival, but falls to an unexpected challenger in the end.

The text reflects the traditional art of wrestling among the Igbo in Nigeria. Although the narrative is didactic, the importance of wrestling to the construction of masculinity in traditional Igbo society is the scaffold for the story. Wrestling, as mirrored in the text, foregrounds the richness of the Igbo's indigenous arts, locally known as Mgba or Ekere Mgba. Mgba is an ancient, masculine sport organised as an annual festival among different communities during seasons when farming is less intensive. Many Igbo societies employ mgba as a rite of passage into manhood, while others utilise it as a bloodless means of settling disputes and wars. Mgba is also essential to the construction of masculinity among the Igbo because matches allow both wrestlers and the winning communities to gain respect by validating their masculinity through strength, skills, and victories. Wrestling stresses the text's alignment with the valorisation of traditional Igbo masculine ideals such as honour, physical strength, hierarchy, 
power, and heterosexual desirability. The opening scene of the text, for instance, demonstrates the importance of wrestling to the honour of both the wrestler and his community: "Echidime village was well known for its wrestling matches. Every year, wrestlers came from different villages to compete in a two-day festival. It was a time of great excitement and festivities for the villagers. Winning a wrestling match here meant a great deal, not only to the winner, but also to the village the winner came from" (Champion 2).

Echidime's masculine values are heralded and honoured through the character of the legendary Dimgba and his relentless pursuit of personal accomplishment as champion of Echidime. At the onset of the story, the people of Echidime express their excitement about Dimgba. As a champion, he is expected to defeat many challengers in his village and age grade before he can fight Mbonu, an equally strong wrestler from a visiting village. Dimgba is able to prove himself capable of overcoming impossible odds by defeating his challengers, including Nwadibia, a notorious herbalist, and eventually overthrowing Mbonu, his fiercest rival. This feat brings honour to him, as well as to his village. This pattern of a wrestler defending his title as champion first before representing his community in wrestling matches highlights the importance of pride, honour, and the test of masculinity that comes with being a champion.

The symbolic relevance of the name Dimgba to the art of wrestling in Igbo society is also significant in the construction of masculinity in the text. Dimgba in Igbo means master wrestler. It has two symbolic meanings. First, it is an Igbo name given to a baby boy at birth which culturally suggests he will turn out to be a wrestler. Second, it is a title awarded to a skilled wrestler who has just won a wrestling tournament. Desch-Obi corroborates that "through the masterful wrestling in inter-village contests, a wrestler can bring honour to his village and will be recognized as a di-mgba and a candidate for heroism" (67). Similarly, Onunwa claims that "one who emerges as the overall winner or champion in the wrestling competition of his Age Grade or in any inter or intra village competition is honoured with the title, Dimgba" (31). Though it is not detailed in the text that Dimgba was his birth name, it is obvious from all indications that he earned the name as a title. He has won many intra and inter-wrestling matches; he is the defending champion of Echidime with outstanding past records. Dimgba is therefore a title owner, due to his feats; he bears the appellation with dignity and pride, just like Okonkwo in Things Fall Apart (Achebe 1), who at the age of 18, defeated the renowned wrestler, Amalinze. It is, however, important to note that many critics have strongly argued that Okonkwo's vision of masculinity is not one that is shared by everyone in the clan. This is because one of the major limitations of Igbo society conveyed in the novel is its flawed idea of masculinity which defines Okonkwo who, perhaps unconsciously but perpetually, exerts to align himself with the socially and complex concept of 'heroism' and 'masculinity'. To Achebe,

This is a society in Things Fall Apart that believes in strength and manliness and the masculine ideals. Okonkwo accepts them in a rather literal sense [...] [and] the culture 'betrays' him. He is 'betrayed' because he's doing exactly what the culture preaches. But you see, the culture is devious and flexible, because if it wasn't it wouldn't survive. The culture says you must be strong, you must be this and that, but when the moment comes for absolute strength the culture says, no, hold it! (Jeyifo 57)

Okonkwo's life is dominated primarily by two things: "the fear of failure and of weakness" (Achebe 12), and his quest to establish himself as one of the greatest men of his clan. What is posited against this concept of weakness is the concept of strength that constructs itself only with the negation of sensitivity. Such construction of strength and masculinity, thus, is in opposition with the values of love, kindness, and compassion that society also expects from men. Hence, this creates multiple and ambiguous masculine identities where Okonkwo is expected to be dominant and sympathetic at the same time. Consequently, Okonkwo displayed more brutal form of masculinity than other male characters in the novel. And he is the sole male character that dies as a result. Although Okonkwo's role in this novel is negative, it is partly used to illuminate the complexity of Igbo notions of masculinity as well as dominant white masculinity. For instance, the excessive brutality of the coloniser, as shown in the novel, leaves itself open to Obierika's statement that "That man was one of the greatest men in Umuofia. You drove him to kill himself; and now he will be buried like a dog [...]" (Things Fall Apart 1l7). From that point of view, we need to look at the factors that are responsible for Okonkwo's downfall vis-à-vis the factors that define his masculinity according to the norms of the society. Okonkwo feeds his family on the chief of crops, yams. Besides his qualities as a wrestler and showing prowess in two inter-tribal wars, he has also taken two titles, he is a wealthy farmer, and he has three wives. 
These positive aspects of Okonkwo's masculinity are what Dimgba represents. Among the Igbo where the narrative is situated, wrestling matches are organised in age grades, but beyond earning titles, a young wrestler can go on to achieve greater things, including becoming a king and an ancestral hero. In the text, the king of the hosting village reveals the prestige that wrestling bestows on males in the society: "once upon a time I was a wrestler. In my youth I was quite the fighter, and you can see where my fighting spirit has brought me. So I say to you all, never underestimate the power of a determined spirit" (Champion 14). Such feats did not only earn the king a higher position in the masculine ladder, but he is also reverenced by his people. He earns respect as a king and as a wrestler. In addition, such wrestlers in the category of the king are known to have their "burial ceremonies marked by the presence of an Agaba masquerade, a symbol of heroic strength and vigour, making their candidacy to become an ancestral hero" (Desch-Obi 67). The graduation from champion wrestler to being a king and eventually a spiritual figure is comparable to the elevation of the male through a variety of masculinities, attaining new powers and responsibilities as one progresses through the hierarchy.

In addition to the honour, prestige, and hierarchical power that winning wrestling matches accrues for Igbo men, winning also attracts sexual gratification, thus confirming women's desirability of such masculinity. Because wrestling brings about security and prestige, popular wrestlers are usually of the most wanted for marriage as part of the dividends that come with holding the Dimbga title (Akubue 180). When Dimgba wins his first set of matches shortly after the commencement of the festival, he decides to relax by moving around the village and baring his body. On sighting the bare-chested Dimgba, one of the ladies in the village remarks, "the dream of every girl is to have a strong man like [Dimgba] as a husband to protect her" (Champion 30). The masculine fantasy offered in the narrative is not just about being powerful and triumphing over oppositions, it is also about winning the affection of beautiful women. Though Dimgba and the lady do not marry, her desire for a man like Dimgba is crucial to the construction of hegemonic masculinity. Onunwa stresses the significance of these relationships in Igbo society: "as a result of the wrestler's exploits, women offer themselves easily to such celebrities for marriage" (30). Similarly, Akubue observes that, "in Igboland, physical education competitions are arranged for peers in order to determine the village champion. As part of the major sport, wrestling produces champion names such as Dimgba, Otiaba, Abaeluana, etc. In effect, winners of the competition become instant toasts of the villages and could, by this singular act, warm their way into the hearts of beautiful brides" (180). In addition, when men are awarded with the best girl as a prize for their bravery and skills, this further highlights the perceived negative image of women in Igbo society as romantic prizes and the weaker gender constantly in need of protection. Although children's literature in Nigeria is witnessing increased numbers of female heroes and protagonists, their depiction of gender is still traditional: men are heroic, strong, and brave; women are damsels in distress, love interests, and romantic prizes.

The text also underlines the significance of drums in the construction of masculinity. Generally, the importance of drums during wrestling festivals is to welcome wrestlers into arenas and create excitement. They are also used to evoke wrestlers' emotion. Wrestlers react to this welcome beat in different ways, ranging from dancing to the beat to show their strength, to shouting their names and raging at their opponents or walking boldly around the arena. In the text, drums play a similar function as Dimgba is seen "walking boldly towards the centre of the festival arena" (Champion 18) after the sound of the drums. The beat of the drums further invokes another level of excitement in Digmba: "instantly, the drummers changed their beat and started to drum a message to Dimgba, encouraging him to fight and defend the honour for which Echidime was known" (18). Here, drumming is introduced to trigger fire and desire in Dimgba to conquer and subdue his opponent. The sound of the drums becomes essential in stirring up emotions in the match to inspire excitement and passion. The effect of the beat of the drums is seen as Dimgba vows "not to let [the people] down" (20). During the excitement of the inspiring drumming, he boasts: "whoever doubts the depth of a great river should step into it" (20). In addition, in the narrative the drum appears as an instrument of power that is only associated with men. Images in the text represent drumming as an exclusive duty of men while women sing and dance, a cultural practice that further constructs gender dichotomy and men's supremacy in society. The arena in the text reinforces drummer/dancer gender roles where drummers are marked as masculine, while dancers are considered feminine. The negative and stereotypic gendering of instruments in the text is seen in many cultures across Africa where the ideas of what is and is not suitable for men and women to do are extremely entrenched in the cultures from which they emerge. 


\section{Folake and Her Four Brothers}

Ifeanyi Ifoegbuna's Folake and Her Four Brothers tells the story of Folake, a thirteen-year-old girl. The story starts with the description of Folake's family - a poor family with Mr. Babaji as the head with a meagre pension; his wife, Mrs. Babaji; and their four children: two girls, and four boys. At age eighteen, Folake's sister, Kacha, is already married to a civil servant with two children. In order to supplement the meagre income of her father, Folake, a brilliant girl in grade six, hawks oranges after school hours while her four brothers who had obtained their school certificates and could not proceed to the university because their parents could not afford the fees, "idled away their time in the house practising wrestling, judo and karate" (Folake 1). Ifoegbuna successfully portrays gender disparity between Folake and her brothers, and between her father and mother. Elements of gender stereotypes are typified when Folake escapes after she is forced into marriage only for her to fall into danger, needing to be saved by her brothers who have been learning martial arts.

While Ikechukwu's text focuses on a wrestling festival, Folake and Her Four Brothers reflects the significance of war dance and song in constructing masculine images of men in traditional Igbo society. This aspect of Igbo culture involves the glorification and expression of high morale in war. In the text, the traditional genre of war dance and songs constructs traits of masculinity in its context, content, and performance. First, in its context, the war dance in the narrative is synonymous with many African war situations. Folake is forced by her father to marry Kassidi, a rich young man, in order to improve their financial status. When Kassidi fails in his attempt to win the Folake's heart in marriage, he arranges to kidnap her. As a member of a cult, Kassidi has the backing of the group's members which also include a chief priest and deadly-looking assassins. When Folake's brothers notice her disappearance, they swing into action by preparing for battle with the cult group: "Folake's four brothers were busy practicing a war dance in the courtyard. People gathered to watch them. They were heavily built, and the crowd admired their vigour and youthfulness" (30). Here, war becomes a masculine art in which physical prowess is displayed to assert the twin qualities of courage and power. The war dance becomes a direct provocation to fight and a part of the battle itself. For the boys, the task of defending and rescuing their sister in the battle against the notorious cult is embraced with the kind of enthusiasm and pride expected of traditional Igbo warriors. A warrior is expected to be glad once an opportunity to fight in a war presents itself. War builds up men's masculinity, and a man's ability in a war is revered if he shows signs of bravery. This idea that there is an inherent value in defending one's masculinity through war is echoed by Okpewho: "once a people have determined to go to war against another people, it is considered cowardly and foolhardy for anyone among them to argue the wisdom of the decision or even attempt to justify it. The warriors are simply glad of an opportunity to show their heroic spirit and have no patience for any form of argument" (152).

Furthermore, during the performance of a war dance, the song that accompanies the dance embodies features of masculinity among the Igbo. In traditional Igbo and other African societies, war songs serve many purposes. Whether they are a mere reinforcement of military strength, an expression of direct incitement to fight, or part of a triumphal procession, war songs are manifestations of manly strength, power, bravery, and honour. Whichever contexts they appear in, such songs are usually "short and onomatopoeic, but mount up to a high pitch of intensity as the men dance, stamping their feet and knocking their shields" (Finnegan 210). In the text, the boys are pictured holding shields, repeatedly dancing and chanting:

Enyimba Enyi!

Nzogbu!

(Folake 31)

Translated from Igbo, the war song means, "Trample, trample, we are like elephants, marching to battle, crushing obstacles on our way". The chant is a well-known traditional war song in Igboland. The song, which originated from the Aba area, specifically during the Aba women riot of 1929, began as a protest song against the British rule in Nigeria. It was one of the songs Aba women composed to exemplify their complaints as they danced and marched to the District Officer to present their petitions. The song has since become popular in contemporary times and has been adopted in many contexts such as war, politics, sport, and traditional wrestling matches to rally "people's solidarity and collective sentiments against any adversarial forces and threats that must be urgently crushed" (Omeje 631). Omeje further explains that, "nzogbu-nzogbu is a song that evokes the idiom of the presumed bravery and fighting prowess of the menfolk, which is likened to the bulldozing power of elephants, which rely on their extraordinary body mass to trample and crush their adversary" (631). The song is, therefore, used in 
the text to inspire optimism and faith in the boys' masculine ability to defeat the notorious cultist. The song also becomes a necessary ingredient in the performance of masculinity that the song represents. For instance, the word "enyi" means 'elephant', an animal with a large body which also symbolises power, strength, and authority. The song focuses on the size and the strength of the animal to intimidate the notorious secret cult known for threatening, kidnapping, killing, and enriching people. The song also features the repetition of "EnyimbaEnyi! Nzogbu!", a refrain to reinforce the intimidation that comes with the performance. The nzogbu-nzogbu philosophy presupposes the certainty of victory in the text. Just like the bulldozing power of elephants, facilitated by their mountainous body mass to crush adversaries, the boys are able to subdue and hand them over to the police.

Like in many African societies, war dance and song are also masculine performance traditions in the narrative. Particularly, the Ohafia people of Igboland have a peculiar dance known as War Dance (Ikpirikpi ogu in Igbo) which is revered as a key masculine performance for celebrating victory in war and bountiful harvest, among others. The four brothers' exhibition of masculinity through their performance of the war dance and song corresponds to the Igbo worldview. They tie a red rope around their heads, waist, and arms. The red rope, a conventional symbol of danger, is associated with the boys' physical strength and their will to fight. It projects a resilient and dominant masculine energy. Moving around in a circle and the stamping of feet on the ground are also indications of excitement, unity, and motivation to take action. This performance also resonates with udje. Similarly, Finnegan points out that during imigubo (a song before going out to fight in Malawi), "men danced in full war dress with shields and spears and performed in the Paramount Chief's village, the traditional place of mobilization. The women too, join in the dance, and the tempo works up and up to inspire the men with the lust for battle" (204). This idea stressed by Finnegan also points to the dichotomy in war dance and song, where men's dominant abilities suppress women's limited roles. In the narrative, this form of performance is reflected where the boys are seen dancing and stamping their feet on the ground while the women's roles are limited to the clapping of hands to the percussive rhythms of the drumming and chanting the boys' praises. The women's morale-imbued chants are an indication of women's recognition of men's patriarchal world that continues to render women as passive and unimportant. As a memorialisation tradition, the war dance propagates the masculine image of the Igbo. Its performance views these ethnic groups as a land of noble warriors. The dance and song structure the social perception of society's gender system as one comprising visible male warriors (Mbah 42) and women singers, and have been a major internal factor in the equation of Nigerian ethnic societies. Hence, war dance and song in its conception and execution deploy masculinity in a variety of ways to achieve hegemonic and ideological goals to readers.

\section{Edidem Eyamba and the Edikang-Ikong Soup}

In Anthonia Ekpa's Edidem Eyamba and the Edikang-Ikong Soup the importance attached to a male child and the justification of polygamy is emphasised from the beginning to the end. It is a story about Edidem Eyamba, a wealthy and powerful king who reigns in Eburutu, a kingdom in Cross River. He is known as a great warrior whose fame spread around Eburutu. Not only is he brave at war, people also know him as a young, handsome ruler who fought in many battles and conquered all the towns and villages close to his kingdom. He also has a large family, comprising of four wives and fifteen girls, prompting a search for a son.

Though the social and cultural perception of a male child is the focus of the text, the importance of oral poetry in the construction of masculinity is conspicuous. The chief purpose of praise poetry among the Igbo is praising or extolling the "virtues of manly prowess, of courage and fighting skills, of exceptional hunting ability, of brave leadership and outstanding physical and behavioural presence" (Turner 196). Praise names can be earned through distinction in various manly activities where a man's valour was put to the test. These praise names could be invented by relatives, contemporaries, the persons themselves, or bards attached to the person if they are kings. Men are judged against this background.

The text illustrates the significance of praise poetry in the validation of strength, wealth, war, and yam cultivation as acceptable traits of masculinity in traditional Igbo society through the character of Edidem Eyamba, the very famous king in Eburutu. In the deployment of praise poetry in the text, especially the heroic praise poems addressed to Edidem by his wives and chiefs, masculinity assumes a heightened form not only in the poetry composition but also in its being geared towards extolling those virtues that the Igbo people hold to be admirable in men. These qualities, sometimes related to warrior virtues, are not only integral parts of the culture but are also seen by the people as meeting established rules of behaviour/conduct and action of men, especially kings. For instance, Edidem is described as a great warrior whose fame is well known all around Eburutu. As a result, elaborate 
praise poems are composed to eulogise his historical character, wealth, heroic deeds, hunting and farming skills, clan, those associated with him, the places he has been, and the realities of the period in which he lives. Praises rendered to him in the narrative stress Edidem's legitimacy as a king who had fought many battles. In a series of Igbo praise-poems composed by his wives during a visit to Edidem, they highlight the king's manly attributes such as virility, bravery, strength, and invisibility, in lofty and effusive language.

Asandia, the second wife, praises the king, establishing a connection between masculinity and praise poetry which social significance is "bound up with the aristocratic nature of African societies, traditionally based on a hierarchy of rank dependent on birth, and linked by an emphasis on the institutions of kingship and chiefship" (Finnegan 39). In making use of these praises, the author uses allusion, metaphor, and exaggerated images that are entrenched in Igbo society to express the courage and ferocity of the king. The author adopts an allusive style, with references to animals, natural phenomena, and historical events that aim to heighten the masculinity of the king. Notable is the frequent comparisons of the king to animals with astounding traits. For instance, his strength is conveyed in metaphorical terms in "the great lion that reigns in Eburutu" (Edidem Eyamba 9). One of his chiefs also extols him as "the tortoise shell which cannot be harmed by the venom of a viper" (10). The subjects of strength, bravery, and heroism echo the king's past heroic deeds and how he has come about his present status. Throughout his past, he "builds a house by the great river" and "swim in the sea and there [he] caught a live crocodile with [his] bare hands" (10). From these praise poems, the subject of bravery, strength, and invincibility as major characteristics of the king's heroism are echoed as reflections of his masculinity. Furthermore, animal metaphors are also used to 'veil' the animals as enemies the king once defeated. In the narratives, the author addresses the king as "the great king that can humble a leopard", "the arrow that blinds the eye of the lion", and "the big sword that cuts through the side of the elephant" (8-10). On the one hand, the animals symbolise the images of the enemies that were subdued by the king in the past, while on the other, the king's ability to defeat these animal-like enemies further reinforces his masculinity.

The narrative is also replete with metaphors of natural phenomena like thunder, wind, trees, and rivers, and to other objects like arrows and swords. It is largely through these figurative and allusive forms of description that actions and qualities of the king are conveyed in the praise poems. Not all forms of "praise poetry take allusion, quite so far, but in general, panegyric seems to exploit allusion and imagery to a higher degree than other forms of poetry in Africa" (Finnegan 117). Hence, in the praise poetry of Edidem, ferocity, strength, bravery, and invulnerability are the masculine qualities exalted. In addition, the poetry highlights how wars, battles, and hunting for survival constitute the important duties of man in traditional Igbo society, especially a king. These qualities and duties, therefore, reinforce the entrenchment of the acceptable masculine stereotypes in both traditional and contemporary times, especially within the context of monarchy. This finding is also echoed by Turner who maintains that praise poetry in Africa reflects references to "virility, sexual prowess, physical attractiveness, strength and fighting" (197) as main qualities that serve to reinforce the entrenchment of the acceptable masculine stereotype in contemporary times.

\section{Conclusion}

In this article I have investigated the cultural construction of masculinity in selected Nigerian children's short stories. Using examples from various Igbo oral and cultural traditions in the texts, I have shown that beyond children's literature being a depository of norms, beliefs, and culture of the Nigerian people, there are visible and strong relationships between oral and cultural traditions and masculinity. I have argued that Igbo oral and cultural traditions present a glorified image of men, and assign them a more elevated social and cultural position. For instance, elements of oral and cultural traditions such as praise names and chants, wrestling festivals, and drums reinforce strength, toughness, honour, protection, respect, big muscles, and the projection of self-pride as acceptable and embraced masculine values in Nigerian society. On the other hand, femininity is associated with meekness, weakness, indignity, powerlessness, and constantly being in need of protection. Oral and cultural traditions continue to play a significant role in terms of social roles and relationships in society. As suggested in the stories, some aspects of culture continue to favour men in the legitimisation of their authority in society. This implies that such notions of masculinity that emerge from oral and cultural traditions provide vicarious pleasure for the male readers who consider them as acceptable norms and values. 


\section{Works Cited}

Achebe, Chinua. Things Fall Apart. William Heinemann, 1958.

Akubue, Godwin B. Cow Without Tail. Dorrance, 2013.

Ayodabo, Sunday J. \& Rowland C. Amaefula. "Continuity and Discontinuity: Masculinity and Power Blocs in African Cinema." Quarterly Review of Film and Video, vol. 38, no. 7, 2021, pp. 654-75. DOI: https://doi.org/10.1080/10509208.2021.187 6482.

Desch-Obi, Thomas J. Fighting for honor: The history of African martial art traditions in the Atlantic world. U of South Carolina P, 2008.

Diala-Ogamba, Blessing. "Folktales as African Children's Literature: A Study of Archetypal Symbols in Selected Igbo

Folktales." ALT 33 Children's Literature \& Story-telling: African Literature Today, edited by Ernest Emenyonu. Boydell \&\& Brewer, 2015 , pp. 54-68.

Ebonogwu, Ikechukwu. The Champion of Echidime. Literamed, 2013.

Ekpa, Anthonia. Edidem Eyamba and the Edikang-Ikong Soup. Literamed, 2009.

Emenyonu, Ernest N. "Selection and Validation of Oral Materials for Children's Literature: Artistic Resources in Chinua Achebe’s Fiction for Children.” Callaloo vol. 25, no. 2, 2002, pp. 584-96. DOI: https://doi.org/10.1353/cal.2002.0065.

Finnegan, Ruth. Oral Literature in Africa. Open Book, 2012.

Ifoegbuna, Ifeanyi. Folake and Her Four Brothers. Literamed, 2004.

Jeyifo, Biodun. "For Chinua Achebe: The resilience and the predicament of Obierika." Kunapipi vol. 12, no. 2, 1990, p. 51-70.

Kiyimba, Abasi. "Gendering social destiny in the proverbs of the Baganda: Reflections on boys and girls becoming men and women." Journal of African Cultural Studies vol. 17, no. 2, 2005, pp. 253-70. DOI: https://doi.org/10.1080/13696850500448360. ."Men and Power: Masculinity in the Folktales and Proverbs of the Baganda." Masculinities in African Literary and Cultural Texts, edited by Helen Mugambi \& Tuzyline Allan. Ayebia Clarke, 2010, pp. 35-49.

Mbah, Leonard N. "Emergent masculinities: The gendered struggle for power in southeastern Nigeria, 1850-1920." Diss. Michigan State U, 2013.

Mfecane, Sakhumzi. “Ndiyindoda' [I am a man]: theorising Xhosa masculinity.” Anthropology Southern Africa vol. 39, no. 3, 2016, pp. 204-14. DOI: http://dx.doi.org/10.1080/23323256.2016.1208535. .

."Towards African-centred theories of masculinity." Social Dynamics vol. 44, no. 2, 2018, pp. 291-305. DOI: https://doi.org 10.1080/02533952.2018.1481683.

Mugambi, Helen N. \& Tuzyline J. Allan. Masculinities in African literary and cultural texts. Ayebia Clarke, 2010.

Nodelman, Perry. “Making boys appear: the masculinity of children's fiction.” Ways of being male, edited by John Stephens. Routledge, 2002, pp. 1-14.

Odimegwu, Clifford, Saseendran Pallikadavath \& Sunday Adedini. "The cost of being a man: social and health consequences of Igbo masculinity.” Culture, health $\sim$ sexuality vol. 15, no. 2, 2013, pp. 219-34. DOI: http://dx.doi.org/10.1080/13691058.2012 .747700 .

Oha, Obododimma. "The semantics of female devaluation in Igbo proverbs." African Study Monographs vol. 19, no. 2, 1998, pp. $87-102$.

Ojaide, Tanure. "Deploying Masculinity in African Oral Poetic Performance: The Man in Udje." Masculinities in African Literary and Cultural Texts, edited by Helen Mugambi \& Tuzyline Allan. Ayebia Clarke, 2010, pp. 66-77. . "Modern African literature and cultural identity." African Studies Review vol. 35, no. 3, 1992, 43-57. DOI: https://doi. org/10.2307/525127.

Okpewho, Isidore. African Oral Literature: Background character and Continuity. Indiana U P, 1992.

Onunwa, Udobata. Studies in Igbo traditional religion. Pacific, 1990.

Omeje, Kenneth. "'Enyimba Enyi': The Comeback of Igbo Nationalism in Nigeria." Review of African Political Economy vol. 32, no. 106, 2005, pp. 630-6.

Ouzgane, Lahoucine \& Robert Morrell. African masculinities: Men in Africa from the late nineteenth century to the present. Springer, 2005.

Ratele, Kopano. "Analysing males in Africa: Certain useful elements in considering ruling masculinities." African and Asian studies vol. 7, no. 4, 2008, pp. 515-36. DOI: https://doi.org/10.1163/156921008X359641.

."Hegemonic African masculinities and men's heterosexual lives: Some uses for homophobia." African Studies Review vol. 57, no. 2, 2014, pp. 115-30. DOI: https://doi.org/10.1017/asr.2014.50.

Sackeyfio, Rose. "Culture \& Aesthetics in Selected Children's Literature by Akachi Ezeigbo." ALT 33 Children's Literature e Story-telling: African Literature Today, edited by Ernest Emenyonu. Boydell \& Brewer, 2015, pp. 6-16.

Turner, Noleen S. "Representations of masculinity in the contemporary oral praise poetry of Zulu men." South African Journal of African Languages vol. 19, no. 3, 1999, pp. 196-203. DOI: https://doi.org/10.1080/02572117.1999.10587397.

Uko, Iniobong. "Contemporary Nigerian Children's Literature: A Study of Ifeoma Onyefulu." ALT 33 Children's Literature e Story-telling: African Literature Today, edited by Ernest Emenyonu. Boydell \& Brewer, 2015, pp. 17-30. 